\title{
木造新築住宅における揮発性有機化合物及びアルデヒド類の発生源調査
}

\author{
斎藤育江 ${ }^{1)}$ ，大貫 文 $^{12}$ ，上原眞一 ${ }^{2}$ ，瀬戸 博 ${ }^{32}$ ，栗田雅行 ${ }^{1)}$ ，小縣昭夫 ${ }^{1)}$ \\ ${ }^{1)}$ 東京都健康安全研究センター環境保健部 †169-0073 東京都新宿区百人町3-24-1 \\ ${ }^{2)}$ 日本生活生協組合連合会・商品検査センター $\mathbf{7} 335-0005$ 埼玉県偋市錦町1-17-18 \\ ${ }^{3)}$ 財団法人 東京顕微鏡院 ₹190-8535 東京都立川市高松町1-100-38
}

\section{Research on emission source of volatile organic compounds and aldehydes in a newly built wooden house}

\author{
Ikue SAITO $^{1)}$, Aya ONUKI ${ }^{1)}$, Shin-ichi UEHARA ${ }^{2)}$, Hiroshi SETO ${ }^{3)}$, Masayuki KURITA ${ }^{1)}$ and Akio OGATA ${ }^{1)}$ \\ ${ }^{1)}$ Tokyo Metropolitan Institute of Public Health 3-24-1 Hyakunin-cho, Shinjuku-ku, Tokyo 169-0073 Japan \\ ${ }^{2)}$ Japanese Consumers' Co-operative Union, 1-17-18 Nishiki-cho, Warabi-shi, Saitama 335-0005 Japan \\ ${ }^{3}$ Tokyo Kenbikyoin Foundation 1-100-38 Takamatsu-cho, Tachikawa-shi, Tokyo 190-8535 Japan
}

\section{要 旨}

床施工に䣷酸ビニル樹脂系接着剂(以下，酢ビ接着剂)を使用した木造一戸建新築住宅において室内空気中 の揮発性有機化合物及びアルデヒド類(以下，揮発性物質)を調査したところ，濃度が高かったのは，アセ卜 アルデヒド，ヘキサナール，ノナナール，酢酸，アセトン，テルペン類 $(\alpha$-ピネン， $\beta$-ピネン，リモネン), パラジクロロベンゼンであった。これらについて発生源を調べたところ，パラジクロロベンゼンを除き，床 下空間が共通の発生場所であると推察された。そこで硬化した酢ビ接着剤から発生する揮発性物質を調査し たところ，樹脂の分解により主に酢酸，アセトアルデヒド，アセトン，䣷酸ビニルモノマーが発生し，その 発生量は湿度の上昇とともに増加した。また，床下が閉鎖的な空間であることから，硬化酢ビ接着剤から発 生した揮発性物質をテドラーバッグに取り分けて濃度変化を調べたところ，実験開始直後に比べて7日間経 過後には，アセトアルデヒド及びアセトンについて2.5倍の濃度増加が見られた。本新築住宅の床構造材に 使用されていた杉はアセトアルデヒド，へキサナール，ノナナール，アセトン，テルペン類を放散すること から，アセトアルデヒド及びアセトンは，構造材及び酢ビ接着剤の両方から発生して床下空間で滞留中にそ の濃度を増し，他の揮発性物質とと屯に内装材の隙間から室内に流入したと推察された。

\begin{abstract}
The measurement of volatile organic compounds (VOCs) and aldehydes in indoor air in a newly built wooden house showed that the concentrations of acetaldehyde, hexanal, nonanal, acetic acid, acetone, terpenes and $\mathrm{p}$ dichlorobenzene were higher than those of other VOCs such as toluene and formaldehyde. An investigation of the emission sources of these compounds revealed that the under flooring space was a common source for all compounds except p-dichlorobenzene. An analysis of the flooring adhesive polymer revealed that water-based polyvinyl acetate (PVA) adhesive had been used during floor construction; therefore, the compounds emitted from a cured PVA adhesive prepared in a laboratory and their degrees of variation with humidity were investigated. It was determined that the cured PVA adhesive predominantly emitted acetic acid, acetaldehyde, acetone and vinyl acetate, and the emission levels increased with humidity. Because the under flooring space has poor ventilation, the emitted compounds from the cured PVA adhesive were collected in a sampling bag made from polyvinyl fluoride film and the concentration change in the compounds was monitored for 7 days. The measurement results on the seventh day showed that the concentrations of both acetaldehyde and acetone were 2.5 times those at the start of the measurement. Considering that coniferous material emits acetaldehyde, acetone, terpenes, hexanal and nonanal, the compounds detected in higher concentrations in the newly built house were believed to be emitted mostly from the PVA adhesive and wood-related construction materials. It was considered that the emitted compounds first stagnated in the under flooring space before gradually leaking into the indoor area through the narrow gaps between the floor materials.
\end{abstract}

Key words: 新築住宅 (newly built house)，揮発性有機化合物 (volatile organic compounds), アセトアルデヒド (acetaldehyde)，発生源(emission source)，酢酸ビニル樹脂系 接着剂(polyvinyl acetate adhesive)

\section{1. 緒言}

1997年に厚生労働省からホルムアルデヒドの室内 濃度指針值 ${ }^{1)}$ が提示されてから10年余りが経過し， 新築住宅におけるホルムアルデヒドの指針值超過率

受付：2010年1月15日(Received：15 January 2010)

受理：2010年3月16日 (Accepted：16 March 2010)
は大幅に低下した ${ }^{2)} 。$ 近年，室内のホルムアルデヒ ド濃度低減対策として合板製造に多用されるように なったのは，酢酸ビニル樹脂系接着剤(以下，酢ビ 接着剂)であり，2008年には年間85万生産されてい る3)。水性形の酢ビ接着剤はトルエン，キシレン等 の有機溶剂を含まないことから揮発性有機化合物 
(以下，VOC) 低減対策にも用いられるが，塗布時 に酢酸, アセトアルデヒド, アセトン等の揮発性物 質を放散することは本誌既報 で報告した。本報に おいては, 近年の住宅室内における空気中化学物質 の実態を調べるため，2006年に竣工した東京都内の 新築住宅1軒について調査を行った。当該住宅では, 床施工に酢ビ接着剤が使用されていたことから, 検 出された揮発性物質之酢ビ接着剤との関連性の有無 を確認し，さらに建物の構造との関連について検討 したので報告する。

\section{2. 方法}

\section{1 試薬}

室内大気分析用標準試薬50成分はSUPELCO製の 試薬を用いた。酢酸ビニルモ)マー(以下, 酢酸ビ ニル), 䣷酸, アセトン及びェ夕ノールは, 和光純 薬工業製の特級試薬を用いた。3-メトキシ-3-メチル ブタン-1-オール(以下, $\mathrm{MMB}$ ) は関東化学製の特級 試薬を用いた。トルエン $-\mathrm{d}_{8}$ は和光純薬工業製の大 気污染物質測定用試薬を用いた。メタノールは和光 純薬工業製の残留農薬・PCB試験用試薬を用いた。 アルデヒド/ケトン-DNPH MIX 15成分はSUPELCO 製の試薬を用いた。アセトアルデヒドはメルク・ジャ パン製の生化学用試薬を用いた。ホルムアルデヒド 液はナカライテスク製の特級試薬を用いた。アセ卜 ニトリルは関東化学製の高速液体クロマトグラフィー 用試薬を用いた。VOC捕集管にはパッシブ用とし てSUPELCO製Tenax TA 200mgを充填したPerkinElmer製ステンレス加熱脱着チューブを用いた。ア クティブ用としてはSUPELCO製Tenax TA 200mg及 びCarbopack B 100mgを充填したPerkin-Elmer製ステ ンレス加熱脱着チューブを用いた。アルデヒド類捕 集管にはパッシブ用としてSUPELCO製DSD-DNPH カートリッジ，アクティブ用としてWaters製の XPoSureカートリッジを用いた。

\section{2 装置}

加熱脱着装置はPerkin-Elmer製ATD-400を用いた。 ガスクロマトグラフ／質量分析計(以下, GC/MS) は島津製作所製GC-17A/QP5050Aを用いた。高速液 体クロマトグラフ (以下, HPLC) は, ポンプに LC10AT, カラムオーブンにCTO-10AC, 紫外線可 視検出器にSPD-10AV, オートサンプラーにSIL10AXLを用い，これらはいずれも島津製作所製で
あった。フーリエ变換赤外分光光度計(以下, FT-IR) は日本分光製のFT/IR-4000を用いた。空気採取ポン プには柴田科学製のミニポンプMP- $\sum 30$ を用いた。 TVOC計は新コスモス電気製のXP-339Vを用いた。

\section{3 分析方法及び条件}

住宅に打ける空気測定及び発生源調査では, VOCの捕集にTenax TAを200mg 充填したステンレ ス加熱脱着チューブ，アルデヒド類の捕集にDSDDNPHを用いた。室内空気は, 捕集管を部屋の中央 付近, 高さ $1.2 \mathrm{~m}$ に設置し, パッシブ法により 24 時 間空気を採取した。発生源調査は天井, 壁, 床につ いて簡易表面空間濃度測定法により実施した。簡易 表面空間濃度測定法は著者らが開発実施してきた空 気採取法で, 測定する建材の表面にパッシブサンプ ラーを置き，その上から $10 \mathrm{~cm} \times 10 \mathrm{~cm}$ そルミ箔を かぶせ, 周辺をテープで貼り付けて, 建材表面付近 の空気を24時間採取する方法である。

硬化酢ビ接着剂を用いた実験では, VOCの捕集 にはTenax TA 200mg及びCarbopack B 100mgを充填 したステンレス加熱脱着チューブを用い，テドラー® バッグ(以下，バッグ)内の空気 $0.2 \mathrm{~L}$ アクティブ法 により採取した。アルデヒド類の捕集には, XPoSureカートリッジを用い, バッグ内の空気 $3 \mathrm{~L} を$ アクティブ法により採取した。

サンプリング後の捕集管は, 厚生労働省の標準的 測定方法 ${ }^{5}$ に準じてVOC及びアルデヒド類を定量分 析した。すなわち，VOCはトルエン- $\mathrm{d}_{8}$ を添加した 後, 加熱脱着装置により $\mathrm{GC} / \mathrm{MS}$ に導入してSCANモー ドで分析した。分析条件をTable 1に示す。なお, 加熱脱着装置の1次脱着温度は, 充填剂がTenax TA の場合は $230^{\circ} \mathrm{C}$, Tenax TA及びCarbopack Bの場合 は $280^{\circ} \mathrm{C}$ とた。アルデヒド類は，アセトニトリル $5 \mathrm{~mL}$ で溶出し, 溶出液を $5 \mathrm{ml}$ にメスアップ後, HPLCにより分析した。分析条件をTable 2に示す。

\section{4 新築住宅における空気中化学物質実態調査}

\section{4.1 室内空気調査}

2006年5月に，2006年2月引渡し，在来工法，2階 建ての新築木造一戸建住宅において空気採取を行い, VOC36種及びアルデヒド類9種の濃度を測定した。 空気採取は1階洋室及び2階和室で行い, 空気採取中, 居住者は平常通りの生活をしていた。測定を行った 各部屋の大きさ及び内装材の種類をTable 3に示す。 
Table 1 Operation conditions for thermal desorption system and GC/MS

\begin{tabular}{ll}
\hline \hline Thermal desorption system & \\
Desorption temp. & $230{ }^{\circ} \mathrm{C}$ or $280{ }^{\circ} \mathrm{C}$ \\
Desorption time & $5 \mathrm{~min}$ \\
Desorption flow & $50 \mathrm{ml} / \mathrm{min}$ \\
In split ratio & $1: 2$ \\
Transfer line temp. & $200{ }^{\circ} \mathrm{C}$ \\
Cold trap temp. low-high (hold) & $4{ }^{\circ} \mathrm{C}-280{ }^{\circ} \mathrm{C}(3 \mathrm{~min})$ \\
Cold trap adsorbent & Tenax TA \\
Out split ratio & $1: 6$ \\
GC/MS & \\
GC Column & $\mathrm{DB}-10.25 \mathrm{~mm}$ i.d. $\times 30 \mathrm{~m}, 1 \mu \mathrm{m}$ \\
Carrier gas & $\mathrm{He}, 50 \mathrm{kPa}$ \\
Detector Temp. & $200{ }^{\circ} \mathrm{C}$ \\
Column temp. & $40{ }^{\circ} \mathrm{C}(3 \mathrm{~min})-12{ }^{\circ} \mathrm{C} / \mathrm{min}-220{ }^{\circ} \mathrm{C}(2 \mathrm{~min})-$ \\
& \\
Acquisition Mode & $\operatorname{SCAN~(m/z~} 45-450)$ \\
\hline
\end{tabular}

Table 2 Operation conditions for HPLC

\begin{tabular}{|c|c|c|c|}
\hline Column & \multicolumn{2}{|c|}{$\begin{array}{l}\text { ZORBAX Bonus RP } \\
4.6 \mathrm{mmi} . \mathrm{d} . \times 5 \mathrm{~cm}, 5 \mu \mathrm{m}\end{array}$} & \\
\hline Column Temp. & \multicolumn{2}{|l|}{$40^{\circ} \mathrm{C}$} & \\
\hline Flow rate & \multicolumn{2}{|c|}{$1.0 \mathrm{ml} / \mathrm{min}$} & \\
\hline Injection vol. & \multicolumn{2}{|l|}{$10 \mu l$} & \\
\hline Wave-length & \multicolumn{2}{|l|}{$360 \mathrm{~nm}$} & \\
\hline Mobil phase solution A & \multicolumn{3}{|c|}{ Acetonitrile $50 \%$ : Water $50 \%$ : Tertahydrofuran $0.1 \%$} \\
\hline \multirow[t]{8}{*}{ Mobil phase solution B } & \multicolumn{3}{|c|}{$\begin{array}{c}\text { Acetonitrile } 80 \% \text { : Water } 20 \% \text { : Tertahydrofuran } 0.1 \% \\
\text { Gragient program }\end{array}$} \\
\hline & Time(min) & $A(\%)$ & $\mathrm{B}(\%)$ \\
\hline & 0 & 70 & 30 \\
\hline & 14 & 70 & 30 \\
\hline & 17 & 0 & 100 \\
\hline & 26 & 0 & 100 \\
\hline & 27 & 70 & 30 \\
\hline & 35 & 70 & 30 \\
\hline
\end{tabular}

Table 3 Size and interior materials in measured rooms

\begin{tabular}{lccc}
\hline \hline & Western style room & Japanese style room \\
\hline location & the first floor & the second floor \\
area $\left(\mathrm{m}^{2}\right)$ & 9.7 & 11.6 \\
height $(\mathrm{m})$ & 2.4 & 2.4 \\
air volume $\left(\mathrm{m}^{3}\right)$ & & 23.3 & 27.8 \\
\hline & floor & flooring board & Tatami* \\
Interior & wall & plaster & PVC $^{* *}$ wall covering \\
material & ceiling & decorated gypsum board & decorated gypsum board \\
\end{tabular}

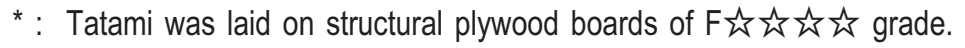

**: polyvinyl chloride.

1階洋室は広さ $9.7 \mathrm{~m}^{2}$, 高さ $2.4 \mathrm{~m}$, 気積 $23.3 \mathrm{~m}^{3}, 2$ 階 和室は広さ $11.6 \mathrm{~m}^{2}$, 高さ $2.4 \mathrm{~m}$, 気積 $27.8 \mathrm{~m}^{3}$ であった。 各部屋の内装は1階洋室では, 床がフローリング,
壁が漆喰，天井が化粧石膏ボード，2階和室では， 床が畳，壁が塩化ビニルの壁紙，天井が化粧石膏ボー ドであった。なお，畳の下にはF々え々えの構造用 
合板が使用されていた。空気測定時の平均室温及び 平均相対湿度は $21.7^{\circ} \mathrm{C}, 44 \%$ であった。

\section{4.2 発生源調査}

2006年6月にアセトアルデヒド，アセトン，ヘキ サナール, ノナナール, 酢酸, $\alpha$-ピネン, $\beta$-ピネン 及びリモネンについて，2階和室で発生源調査を行っ た。調査に用いた簡易表面空間濃度測定法では, 内 装材表面の濃度が室内空気中濃度の2倍を超えた場 合に，化学物質の発生があると判定した。なお，発 生源調査を行った場所は, 天井, 壁, 畳及び畳下 の構造用合板で，構造用合板については畳を1枚上 げ，継目の無い合板上及び $3 \mathrm{~mm}$ 程度の隙間がある 継目上で調査した。なお，合板の継目は畳下に数力 所あったため, 測定ポイントの選定に際しては TVOC計を用い，表示数值が相対的に高かったポイ ントを測定場所とした。発生源調査と同時に, 室内 空気についてパッシブ法による測定を行った。発生 源調査時の平均室温及び平均相対湿度は $23.5^{\circ} \mathrm{C}, 74$ \%であった。また, 発生源調査の際に, 畳下の構造 用合板表面に固着していた接着剤の少量をカッター ナイフで切り出し, FT-IRスペクトルを測定して樹 脂の同定を行った。

\section{5 硬化酢ビ接着剂を用いた実験的検討}

\subsection{1 硬化酢ビ接着剂から発生する揮発性物質の測定}

硬化酢ビ接着剂の調製は，まず，市販の木工・内 装用接着剤をガラス板に塗布して約 $0.1 \mathrm{~g} / \mathrm{cm}^{2}$ となる よう広げた。5〜6時間養生後に接着剤が半透明膜状 に硬化したことを確認後, 膜状のままガラス板から はがし, 室内で3カ月風乾した後に実験に使用した。 乾燥後の重量は $0.03 \sim 0.05 \mathrm{~g} / \mathrm{cm}^{2}$ であった。用いた接 着剂の成分は，酢酸ビニル樹脂 $41 \%$, 水分 $59 \%$ 之表 示されていた。

硬化酢ビ接着剂から発生する揮発性物質を測定す

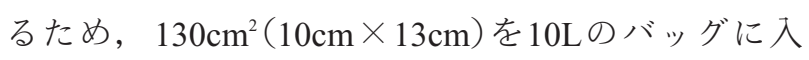
れ，ポンプで空気を抜いた後，相対湿度 $15 \%, 45 \%$,

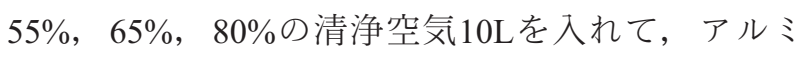
製バッグで包んで遮光し， $25^{\circ} \mathrm{C}$ で48時間静置後，バッ グ内の空気を採取し, VOC及びアルデヒド類を分 析した。

\subsection{2 閉鎖空間における揮発性物質の濃度変化}

閉鎖空間における硬化酢ビ接着剤由来揮発性物質 の濃度変化を調查した。硬化酢ビ接着剂由来の揮発 性物質は，硬化酢ビ接着剂 $900 \mathrm{~cm}^{2}(30 \mathrm{~cm} \times 30 \mathrm{~cm})$ を
30Lのバッグに入れ，相対湿度 $80 \%$ の清浄空気を入 れてアルミ製バッグで包んで遮光し， $25^{\circ} \mathrm{Cで} 24$ 時間 静置して調製した。次に調製したガスを別のバッグ に移してアルミ製バッグで包んで遮光し， $25^{\circ} \mathrm{C}$ で7 日目までの経時变化を調査した。バッグ内のガスは 調査開始直後，3日後及び7日後に採取し，VOC及 びアルデヒド類を分析した。

\section{3. 結果}

\section{1 新築住宅における空気中化学物質実態調査}

\section{1.1 室内空気測定結果}

測定結果をTable 4 に示す。1階洋室及び2階和室 で高濃度に検出された物質は共通しており， $\alpha$-ピネ ンが洋室で $699 \mu \mathrm{g} / \mathrm{m}^{3}$, 和室で $1,090 \mu \mathrm{g} / \mathrm{m}^{3}$, パラジク ロロベンゼンが洋室で $312 \mu \mathrm{g} / \mathrm{m}^{3}$, 和室で $703 \mu \mathrm{g} / \mathrm{m}^{3}$, 酢酸が洋室で $188 \mu \mathrm{g} / \mathrm{m}^{3}$, 和室で $93.6 \mu \mathrm{g} / \mathrm{m}^{3}$ であった。 1階洋室よりも2階和室の方が濃度が高い傾向がみら れた。また, 厚生労働省から室内濃度指針值 ${ }^{5}$ が示 されている物質については, アセトアルデヒド及び パラジクロロベンゼンが洋室, 和室ともに指針值を 超過していた。

\section{1.2 発生源調査結果}

発生源調査の結果をTable 5に示す。測定対象と したアセトアルデヒド，ヘキサナール，ノナナール， アセトン, 酢酸, $\alpha$-ピネン, $\beta$-ピネン及びリモネン は, 室内空気調査において $50 \mu \mathrm{g} / \mathrm{m}^{3}$ 以上の濃度で検 出された物質である。测定物質と発生場所との関係 をみると, 天井では酢酸, 壁では酢酸, $\beta$-ピネン及 びリモネン，畳ではノナナール，酢酸， $\alpha$-ピネン， $\beta$-ピネン及びリモネン，畳下の構造用合板では酢酸， 畳下構造用合板の継目 (以下, 継目)では8物質すべ てが室内空気中濃度の2倍以上の濃度を示し，それ ぞれの発生源であると推察された。また，物質ごと に各測定場所の濃度を比較すると， $\alpha$-ピネンを除き， 継目の部分が最も高濃度を示し，その原因として， 継目の隙間から室内に流入した床下空気に高濃度の 揮発性物質が含まれていたことが推察された。 $\alpha$-ピ ネンは畳が最も高濃度を示した。

\section{1.3 床施工に使用された接着剤樹脂の同定}

硬化した接着剤について，FT-IRにより分析を行 い得られたIRスペクトルをFig.1に示す。図中の (A) は新築木造住宅の構造用合板に付着していた試料, （B）は市販の酢ビ接着剤を硬化させた試料を表す。 (A)では，エステル結合の $\mathrm{C}=\mathrm{O}$ に由来する $1020 \mathrm{~cm}^{-1}$, 
Table 4 Indoor air aldehydes and VOCs in a newly built house $\left(\mu \mathrm{g} / \mathrm{m}^{3}\right)$

\begin{tabular}{|c|c|c|c|}
\hline \multirow[b]{2}{*}{ Compounds } & & \multicolumn{2}{|c|}{ Indoor air } \\
\hline & & Western style room & Japanese style room \\
\hline \multirow[t]{10}{*}{ Aldehydes and acid } & Formaldehyde & 34.7 & 39.0 \\
\hline & Acetaldehyde & 53.1 & 89.1 \\
\hline & Propionaldehyde & 5.1 & 9.8 \\
\hline & Pentanal & 18.9 & 28.1 \\
\hline & Hexanal & 75.1 & 113 \\
\hline & Nonanal & 64.1 & 64.0 \\
\hline & Decanal & 37.3 & 13.5 \\
\hline & Benzaldehyde & 16.0 & 23.1 \\
\hline & Cyclohexanone & 13.8 & 17.7 \\
\hline & Acetic acid & 188 & 93.6 \\
\hline \multirow[t]{3}{*}{ Ketons } & Acetone & 68.6 & 96.1 \\
\hline & 2-Butanone & 11.2 & 17.0 \\
\hline & 4-Methyl-2-pentanone & 4.8 & 7.2 \\
\hline \multirow[t]{4}{*}{ Alcohols } & Ethanol & 16.2 & 25.1 \\
\hline & 2-Propanol & 2.7 & 4.1 \\
\hline & Butanol & 8.7 & 13.5 \\
\hline & 3-Methyl-3-methoxybutanol & 9.9 & 30.0 \\
\hline \multirow[t]{2}{*}{ Esters } & Ethyl acetate & 3.1 & 3.6 \\
\hline & Butyl acetate & 25.2 & 31.6 \\
\hline \multirow[t]{11}{*}{ Alkans } & Hexane & 7.7 & 5.7 \\
\hline & Heptane & 1.4 & 1.8 \\
\hline & Octane & 3.5 & 4.4 \\
\hline & Nonane & 1.6 & $<1.0$ \\
\hline & Decane & 10.4 & 12.5 \\
\hline & Undecane & 17.8 & 23.1 \\
\hline & Dodecane & 11.7 & 7.0 \\
\hline & Tridecane & 9.2 & 5.8 \\
\hline & Tetradecane & 11.8 & 8.0 \\
\hline & Pentadecane & 4.1 & 2.7 \\
\hline & Hexadecane & 5.2 & 2.3 \\
\hline \multirow[t]{9}{*}{ Aromatics hydrocarbones } & Benzene & 1.2 & 1.1 \\
\hline & Toluene & 20.4 & 31.8 \\
\hline & Xylene & 3.6 & 6.5 \\
\hline & Styrene & 4.5 & 3.2 \\
\hline & Ethyltoluene & 11.8 & 18.1 \\
\hline & 1,3,5-Trimethylbenzene & 3.6 & 5.4 \\
\hline & 1,2,4-Trimethylbenzene & 11.4 & 15.0 \\
\hline & 1,2,3-Trimethylbenzene & 5.0 & 5.9 \\
\hline & 1,2,4,5-Tetramethylbenzene & 1.8 & 1.2 \\
\hline \multirow[t]{3}{*}{ Terpens } & a-Pinene & 669 & 1,090 \\
\hline & $\beta$-Pinene & 47.7 & 76.2 \\
\hline & Limonene & 65.9 & 120 \\
\hline Halogenated hydrocorbons & Dichloromethane & 2.9 & 7.2 \\
\hline \multirow[t]{2}{*}{ Compounds } & Chloroform & 1.8 & 3.7 \\
\hline & p-Dichlorobenzene & 312 & 703 \\
\hline
\end{tabular}


Table 5 Volatile chemical concentrations in indoor air and material surface area in the Japanese style room $\left(\mu \mathrm{g} / \mathrm{m}^{3}\right)$

\begin{tabular}{|c|c|c|c|c|c|c|}
\hline \multirow[t]{2}{*}{ Compounds } & \multirow[t]{2}{*}{ Indoor air } & \multicolumn{3}{|c|}{ Surface on interior materials ${ }^{*}$} & \multicolumn{2}{|c|}{ Surface on structural materials* } \\
\hline & & Ceiling & Wall & $\begin{array}{c}\text { Floor } \\
\text { (Tatami) }\end{array}$ & $\begin{array}{l}\text { Plywood } \\
\text { board }^{* *}\end{array}$ & $\begin{array}{l}\text { Gap between } \\
\text { plywoodboards** }\end{array}$ \\
\hline Acetaldehyde & 70.6 & 11 & 42 & 55 & 19 & 230 \\
\hline Hexanal & 66.7 & 16 & 37 & 57 & 54 & 170 \\
\hline Nonanal & 50.9 & 58 & 81 & 103 & 97 & 108 \\
\hline Acetic acid & 58.3 & 140 & 560 & 590 & 1,900 & 2,500 \\
\hline Acetone & 71.8 & 9 & 70 & 68 & 36 & 360 \\
\hline a-Pinene & 1,080 & 900 & 1,100 & 6,500 & 380 & 2,500 \\
\hline$\beta$-Pinene & 67.7 & 54 & 190 & 230 & 25 & 690 \\
\hline Limonene & 131 & 140 & 490 & 390 & 82 & 2,200 \\
\hline
\end{tabular}

* Air sampling method was as follows; passive gas tubes were placed in contact with the surface of the interior or structural materials, then the tubes were covered with aluminum wrap and edges of the wrap were sealed with adhesive tape during sampling period (24h).

** The plywood boards were laid under the Tatami.

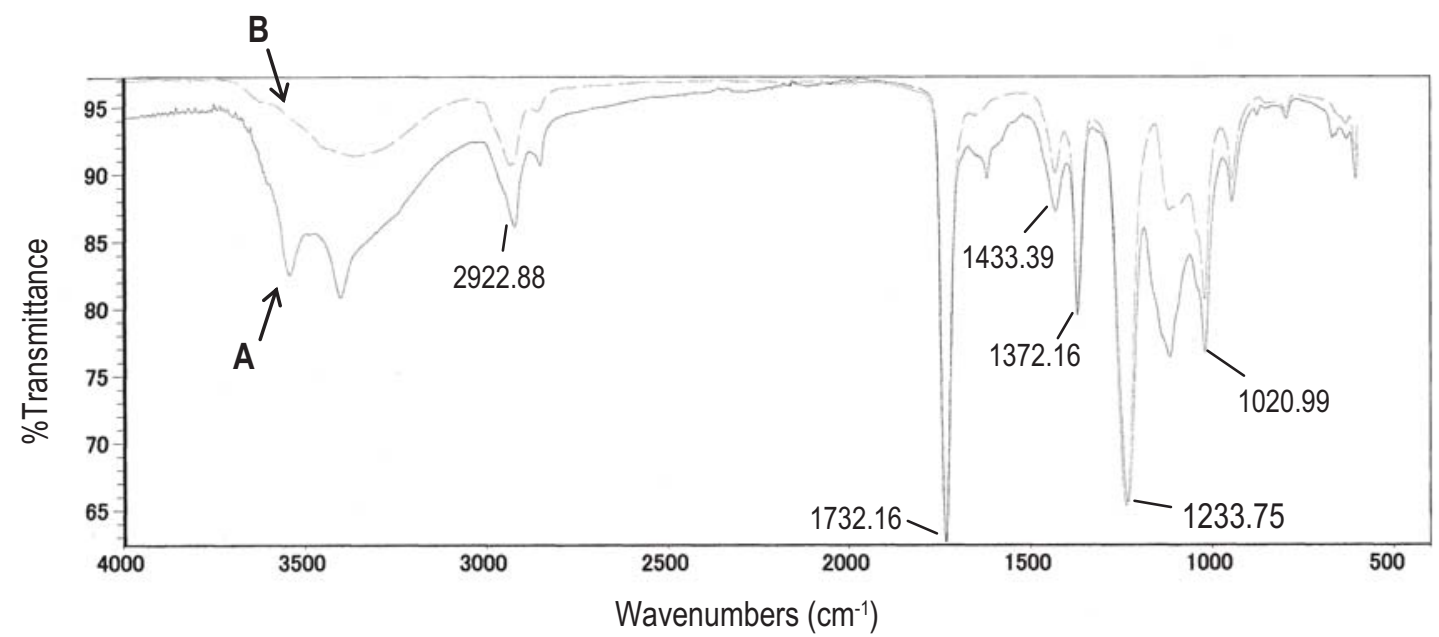

Fig.1 IR spectrums of cured adhesive sampled in the newly built house and prepared in a laboratory

A : Cured adhesive stuck to plywood in the new built house

$B$ : Cured polyvinyl acetate (PVA) adhesive prepared in a laboratory

$1230 \mathrm{~cm}^{-1}$, メチル基とメチレン基のC-Hの变角振動 に由来する $1375 \mathrm{~cm}^{-1}$ 及び $1440 \mathrm{~cm}^{-1}$, カルボニル基のC $=$ O伸縮に由来する $1740 \mathrm{~cm}^{-1}$ ，メチル基，メチレン基 及びメチン基のC-Hの伸縮振動に由来する2900〜 $3000 \mathrm{~cm}^{-1}$ が確認された。また，（A）と（B）はよく一 致したことから, 接着剂樹脂の種類はポリ酢酸ビニ ル樹脂であることが判明した。

\section{2 硬化酢ビ接着剂を用いた実験的検討}

\section{2.1 硬化酢ビ接着剤から発生する揮発性物質}

酢ビ接着剂は, 硬化後, 加水分解によって䣷酸, アセトアルデヒド，アセトンを放散するとの報告(6) がある。そこで継目から高濃度に検出され, 床下か
らの流入が推察された揮発性物質の発生源を調査す るため, 硬化した酢ビ樹脂接着剤から発生する揮発 性物質を測定し, その濃度と湿度との関連を調查し た。結果をFig.2に示す。発生が認められた主な揮 発性物質は, 酢酸, MMB, アセトン, 酶酸ビニル, アセトアルデヒド，ホルムアルデヒド及びェタノー ルであり,これらのうち発生量の多かった物質は䣷 酸及びMMBであった。また, 湿度の上昇に伴って 発生量が増加し，相対湿度が $45 \%$ を超えるといずれ の物質においてもその量は顕著に増大した。特に酢 酸ビニルについては湿度上昇に伴う発生量の増大割 合が最も大きく, 相対湿度 $80 \%$ では相対湿度 $45 \%$ に 比べ，濃度が64倍に急増していた。著者らは本誌既 

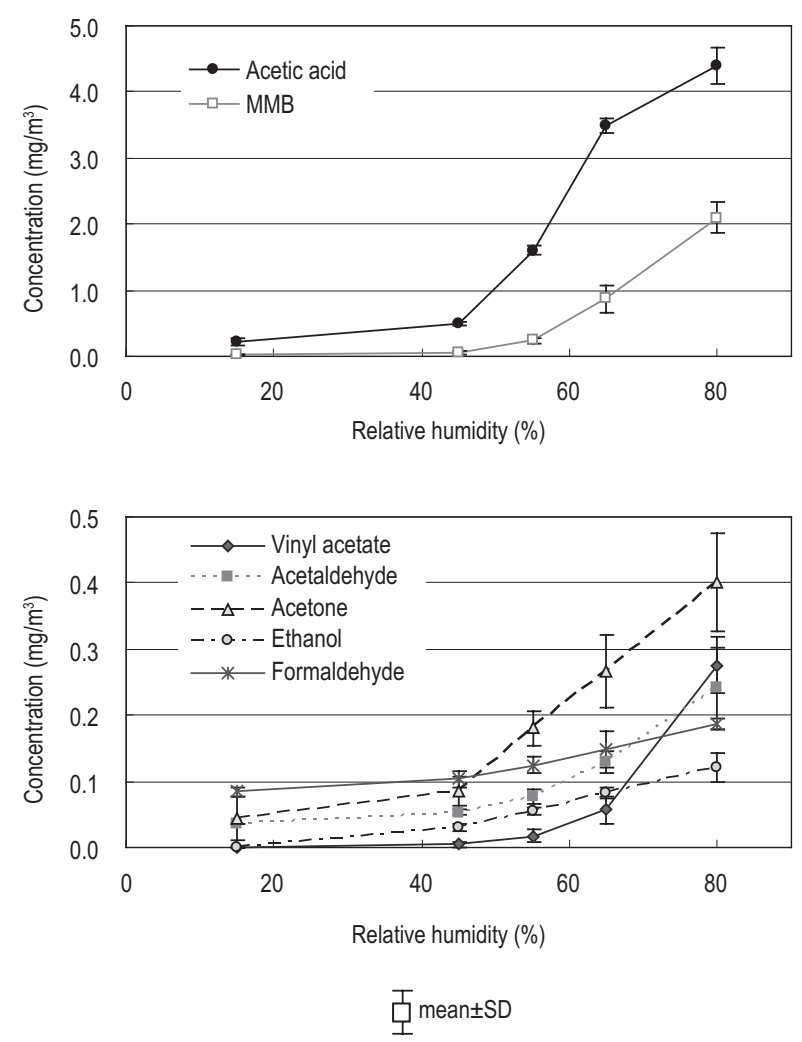

Fig.2 Relationship between relative humidity and concentration of volatile chemicals emitted from cured PVA adhesive

Cured PVA adhesive was packed in the Tedlar $^{\circledR}$ Bag with clean air of various humidity $(n=3)$. After 48 hours, an aliquot of air in the Tedlar $^{\circledR}$ Bag was sampled, and concentration of volatile chemicals were analyzed.

報出において，塗布直後の未硬化酢ビ接着剤から発 生する揮発性物質について報告したが，検出された 主な物質は酢酸，MMB，アセトン，酢酸ビニル， アセトアルデヒド，ホルムアルデヒドであった ${ }^{4)}$ 。 したがって硬化酢ビ接着剤は，加湿により塗布直後 の未硬化接着剂と同様の化学物質を放散することが 明らかになった。

\section{2.2 閉鎖空間における揮発性物質の濃度時変化}

閉鎖的な床下空間に揮発性物質が滞留した場合の 経時的変化を調査した。結果をFig.3に示す。酢酸, $\mathrm{MMB}$ ，酢酸ビニル，ホルムアルデヒドについては 経時的に濃度の減少がみられ，初期濃度を $100 \%$ と した場合の7日目の濃度は減少の大きかったものか ら順に酢酸 $46 \%$ ，酢酸ビニル $58 \%$ ，ホルムアルデヒ ド 63\%，MMB75\%，であった。これに対しアセト ン，アセトアルデヒド及びェタノールについては濃 度の増加がみられ，初期濃度に対する7日目の濃度
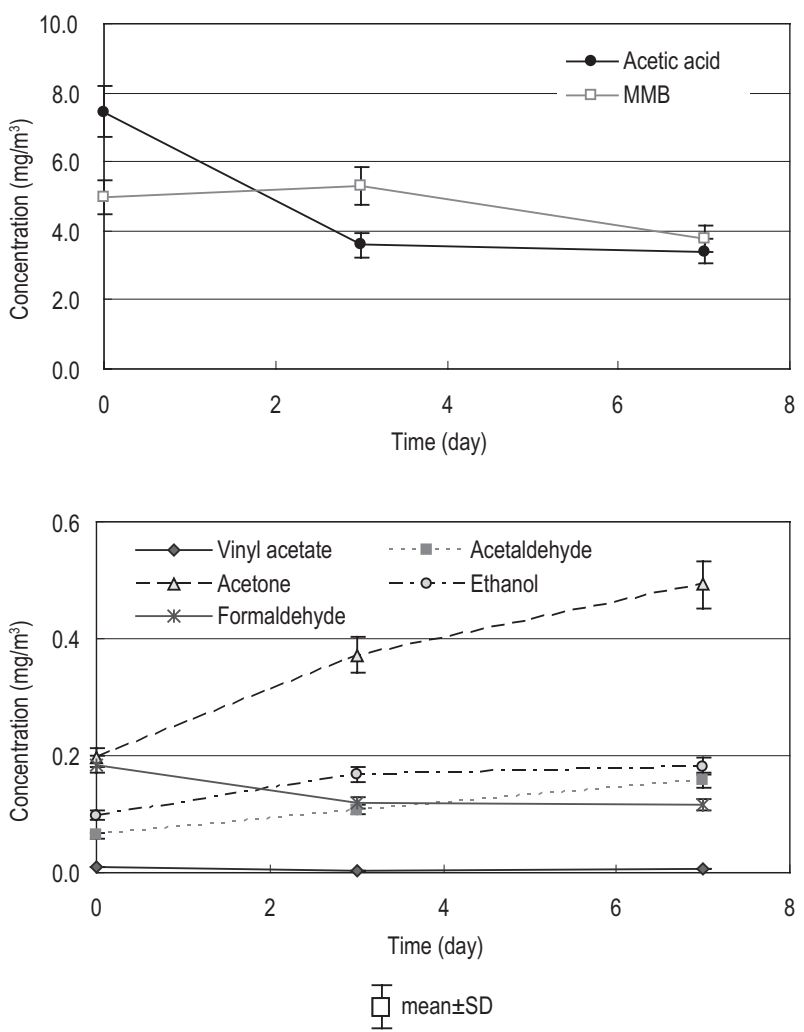

Fig.3 Concentration change of volatile chemicals in Tedlar ${ }^{\circledR}$ Bag which emitted and separated from cured PVA adhesive

Cured PVA adhesive was placed in the Tedlar $^{\circledR}$ Bag with clean air of $80 \%$ relative humidity. After 24 hours, the gas in the $\operatorname{Tedlar}^{\circledR}$ Bag was moved to other Bags, and concentration change of volatile chemicals was monitored for 7 days $(n=3)$.

は, アセトン 2.5 倍, アセトアルデヒド 2.5 倍, エ夕 ノール1.8倍であった。

\section{4. 考察}

\section{1 揮発性物質の発生源について}

発生源調査において，アセトアルデヒド，ヘキサ ナール，ノナナール，酢酸，アセトン， $\alpha$-ピネン， $\beta$-ピネン及びリモネンは畳下の構造用合板継目で空 気中濃度より2倍以上高濃度を示した。このことは, これらの共通した発生場所は2階の床下であること を示している。在来工法の木造一戸建住宅における 2階床下空間は， $40 \mathrm{~cm} \sim 60 \mathrm{~cm}$ 高さがあるのが一般 的で, 2階床の下地材, 梁, 1階天井の下地材, 壁下 地材等に囲まれた閉鎖的空間となっている。住宅の 垂直断面困の例をFig.4に示す。木造住宅において は構造材及び下地材として多用される杉や松等の針 葉樹は，アセトアルデヒド，アセトン， $\alpha$-ピネン， 


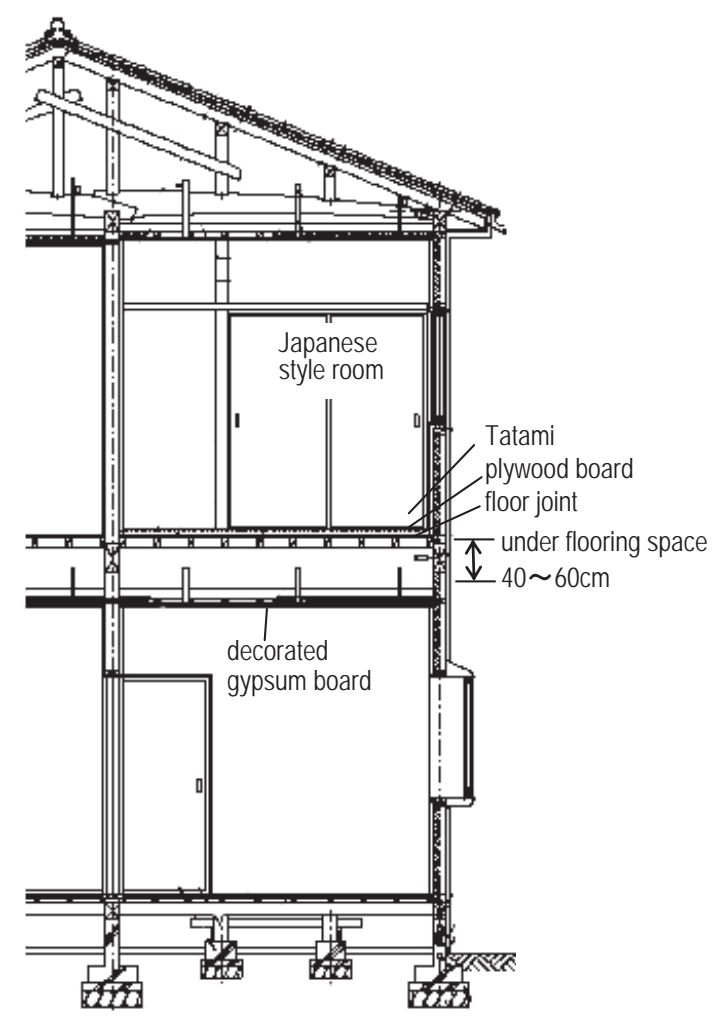

Fig.4 Schematic drawing of vertical section of a wooden house

及-ピネン, リモネン，ヘキサナール，ノナナール等 を放散するとの報告がある7)。また, 今回の研究で は床用接着剤として使用された酢ビ接着剤が，硬化 後も加湿によって酢酸, アセトアルデヒド, アセト ン等を発生しうることを実験的に確認した。したがっ て，調査した住宅が在来工法であり，建築の木質建 材に針葉樹が，接着剤として酢ビ接着剤が使用され ていることを考えると，ヘキサナール，ノナナール， $\alpha$-ピネン， $\beta$-ピネン及びリモネンは木質建材から， 酢酸は接着剂から，アセトアルデヒド及びアセトン は木質建材及び接着剂から発生し，換気の少ない床 下空間に滞留して濃度を高め, 板と板の隙間から徐々 に室内に放散されている状況が考えられた。また， 構造用合板以外に, 室内の床, 壁, 天井の各部位な ど背面に空間を有する部分をTVOC計で測定すると, フローリング板の継目，床と壁の合わせ目，壁と天 井の合わせ目等で高い表示值を示す場所が多数あり, 建物の躯体内部の空間に滞留した揮発性物質は, 内 装材隙間のいたるところから室内に流入しているも のと推察された。

空気測定では，2階和室だけでなく1階洋室におい てもアセトアルデヒドの室内濃度が厚生労働省の指 針值 ${ }^{5}$ を超過していた。しかし，1階洋室で後に行っ
た壁及び床についての発生源調査ではアセトアルデ ヒドの発生は認められず，TVOC計による調査では， 壁と天井の合わせ目で最高值を示した。したがって， 1階洋室におけるアセトアルデヒドの発生源は, 天 井及び天井裏であることが示唆され，1階と2階の間 の閉鎖空間に滞留した揮発性物質は上下両方の室内 に影響を及ぼしている可能性が考えられた。

$\alpha$-ピネンは畳において最高濃度を示したが，この 理由としては，構造用合板から発生した $\alpha$-ピネンが 畳に吸着していたこと，また畳床に使用されている 木質性のファイバーボードが $\alpha$-ピネンを発生してい たことなどによるものと推察された。

パラジクロロベンゼンについては，居住者に対す る聞き取り調查により，2階和室のタンスで防虫剂 としてパラジクロロベンゼン製剤を使用していたこ とが確認された。住宅の物置等でパラジクロロベン ゼン製剤とカップ麺を同時に保管し, カップ麺の容 器外側からガス状のパラジクロロベンゼンが浸潤し て内部の湎を污染したのではないかと疑われる事件 について，2008年10月に報道があり ${ }^{8)}$ ，いまだ防虫 剂として本薬剂が室内濃度指針值を超えるような使 われ方をしている例が示された。

室内に拈けるアセトアルデヒドの発生源について 炭素の放射性同位体 $\left({ }^{14} \mathrm{C}\right)$ を指標として調査した結 果では，木材由来と考えられるアセトアルデヒドの 割合は49〜67\%程度との報告がある ${ }^{9,10)}$ 。したがって 室内のアセトアルデヒド低減対策は, 木質建材に対 する放散抑制だけでは十分とは言えず，現在のとこ ろ有効な対策が見出されていない。本研究では床下 空間に㧍いて，硬化酢ビ接着剂由来のアセトアルデ ヒドの生成促進が明らかになったことから，今後の アセトアルデヒド低減対策に有用な知見と考えられ る。

\section{2 硬化酢ビ接着剂由来揮発性物質の発生機構に ついて}

ポリ酢酸ビニル樹脂は, ポリビニルアルコールに アセチル基がエステル結合した構造を持つが，更に アセチル基からの分岐を多く持つのが特長である ${ }^{11}$ 。 したがって，酢ビ樹脂は水分と反応すると，アセチ ル基が加水分解し酢酸を発生する ${ }^{12)}$ 。硬化酢ビ接着 剂からの発生が認められた物質のうち, 酢酸及び酢

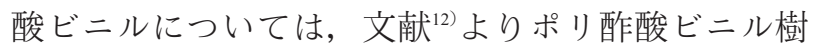
脂の分解により生成したと考えられるが，本実験が， 
テドラーバッグ内で48時間中に生成する揮発性物質 を測定したものであるため，アセトアルデヒド，ア セトン, エタノールについては, 樹脂の分解及びそ の後の揮発性物質の反応によって生成したものが混 合していると考えられた。また，MMBは樹脂の分 散剤として製品に添加されていることから ${ }^{4)}$, 樹脂 に含まれていたものが遊離したと考えられ，ホルム アルデヒドは酶酸ビニルの不純物として含まれるギ 酸ビニルに由来するあの ${ }^{13)}$ と推察された。また，本 研究により加湿による酢酸ビニル樹脂の分解促進が 示されたことから，䣷ビ接着剂からの揮発性物質の 発生量は, 夏期に多く冬期に少ないという季節变動 を示しながら，比較的長期にわたって放散が続くこ とが予想された。なお，今回の実験に使用した硬化 酢ビ接着剂は, 新築住宅の築後月数を考慮して硬化 後3カ月の養生期間を置いたものであったが，養生 期間が 1 週間程度のもので揮発性物質を測定したと ころ, その発生量は本実験で使用したものよりも約 10倍多かった。

硬化酢ビ接着剂から発生する揮発性物質は, 酢酸 に次いでMMBが高濃度であったのに対し, 住宅に おける $\mathrm{MMB}$ 濃度は 2 階和室で $30 \mu \mathrm{g} / \mathrm{m}^{3}$ 之低かった。 MMBは溶剤ではなく樹脂の分散剤であるが，沸点 としてはVOCに区分されることから，メーカーで は2004年9月から製品へのMMB添加量を減らしてい る ${ }^{14)}$ 。今回の実験で硬化酢ビ接着剤を調製するため に購入した木工用接着剤は2004年8月に購入したも のであったため, 近年使用されている製品よりも MMB含有量が多く, そのために硬化酢ビ接着剂を 用いた実験においてはMMBの発生量が多かったと 考えられた。

\section{3 閉鎖空間における揮発性物質の経時変化について}

硬化酢ビ接着剤由来の揮発性物質について閉鎖空 間における濃度变化を調査した結果, 時間経過とと 屯にアセトン，アセトアルデヒド及びェタノール濃 度の増加がみられたが, その一因として濃度減少を 示した酢酸及び䣷酸ビニルからの生成が考えられた。 すなわちアセトンについては, 酢酸 2 分子が脱炭酸 することによって生成し ${ }^{15)}$ ，アセトアルデヒド及び エ夕ノールについては, 酶酸ビニルが加水分解して, アセトアルデヒド及びビニルアルコールが生成し, ビニルアルコールは不安定であるために, アセトア ルデヒドあるいはエ夕ノールに变化することが考え
られた。また, 酢ビ樹脂の分解物として, 酢酸ビニ ルオリゴマーなど，比較的分子量の大きい準揮発性 有機化合物 (SVOC)の生成が推察され, これらの分 解によりアセトン, アセトアルデヒド及びェ夕ノー ルが生成する可能性も考えられた。しかし, 今回の 研究に用いた分析手法は, SVOCの分析には対応し ていなかったため, 反応機構の詳細については今後 の検討が必要と考えられた。

木質建材から発生する $\alpha$-ピネンは大気中でヒドロ キシラジカルとの反応により, 一部がアセトアルデ ヒドに变化することが報告されている ${ }^{16)}$ 。今回の調 查で, $\alpha$-ピネンは室内空気中から最も高濃度に検出 されていたことから, 室内に打ける $\alpha$-ピネンの挙動 については今後の調査が必要と考えられた。

\section{5. 結論}

東京都内の新築住宅1軒について室内空気中の化 学物質を調査したところ, 検出された揮発性物質の うち, $50 \mu \mathrm{g} / \mathrm{m}^{3}$ 以上の高濃度を示したものはアセ卜 アルデヒド, ヘキサナール, ノナナール, 酢酸, ア セトン, $\alpha$-ピネン, $\beta$-ピネン, リモネン及びパラジ クロロベンゼンの9物質であった。発生源調査の結 果, これらの共通の発生場所は, パラジクロロベン ゼンを除き, 2階床下空間であることが判明し, 発 生源については, アセトアルデヒド, ヘキサナール, ノナナール, アセトン, $\alpha$-ピネン, $\beta$-ピネン, リモ ネンは床構造材の針葉樹, アセトアルデヒド, 酷酸, アセトンは床施工に使用された酢ビ接着剂に由来す るあのであると推察された。本研究においては, 酢 ビ接着剂の分解が湿度に依存して促進され, 分解に より生成する揮発性物質が床下等の閉鎖空間に存在 した場合，アセトアルデヒド，アセトン及びエタノー ルの生成が促進されることが示唆された。また, 建 物の構造との関係では, 床下等の内装材の背面空間 には, 木材あるいは接着剤等から発生した揮発性物 質が滞留し, それらが内装材の隙間から徐々に室内 に放散されていることが明らかになった。したがっ て, 快適な室内環境を保っためには, 床下, 壁裏, 天井裏の空間に建材由来の揮発性物質が滞留しない 工夫, また滞留した揮発性物質が室内に流入しない 工夫など，建物の躯体内部空間に対する対策が，今 後求められる新たな課題と考えられた。 


\section{引用文献}

1）厚生省「快適で健康的な住宅に関する検討会議」： ホルムアルデヒドの室内濃度指針值, 平成9年6 月.

2）国土交通省：平成17年度 室内空気に関する実 態調査報告書, 平成18年11月.

3）日本接着剂工業会：統計情報.

http://www.jaia.gr.jp/05toukei.html

4）斎藤育江, 大貫 文, 瀬戸 博, 上原眞一, 上 村 尚: 水性形接着剂から放散される化学物質 による室内污染濃度の予測, 室内環境学会誌, 18, p.15-26(2005).

5）厚生労働省：室内空気中化学物質の室内濃度指 針值及び標準的測定方法等について, 医薬発第 0207002号, 平成14年2月7日.

6）堀 雅宏, 韓 玨, 下之園 孝: 室内環境にお けるアセトアルデヒドの生成メカニズム, 日本 環境管理学会室内環境学会合同研究発表会講演 予稿集, p.102-103(2004).

7）塔村真一郎, 宮本康太, 井上明生 : ホルムアル デヒド放散等級の異なる合板から放散されるア ルデヒド類及び揮発性有機化合物 (VOC) の測 定，木材学会誌，51，p.340-344(2005).

8）毎日新聞：カップめん 防虫剂成分検出，2009 年10月24日 朝刊.

9) Yoshimi Kato, Naohide Shinohara, Jun Yoshinaga, Masao Uchida, Ayuri Matsuda, Minoru Yoneda and Yasuyuki Shibata : Deternimation of ${ }^{14} \mathrm{C} /{ }^{12} \mathrm{C}$ of acetaldehyde in indoor air by compound specific radiocarbon analysis, Atmospheric Environment, 42, 1049-1056(2007).

10）中西準子, 篠原直秀, 納屋聖人：詳細リスク評 価書シリーズ11アセトアルデヒド, NEDO技術 開発機構・産業技術総合研究所化学物質リスク 管理研究センター編, 丸善, p.148-149(2007).

11）高分子学会：新高分子実験学第 5 巻高分子の構 造(1) 一磁気共鳴法一, 共立出版, p.105(1995).

12）三田 達：高分子大事典, 丸善株式会社, p.856(1994).

13）村橋俊介, 小田良平, 井本 稔: プラスチック ハンドブック，朝倉書店，p.292(1966).

14）水町 浩, 福沢敬司, 若林一民, 杉井新治: 接 着大百科, p.276-290(1997).

15) M. A. Hasan, M. I. Zaki and L. Pasupulety : Oxidecatalyzed conversion of acetic acid into acetone : an FTIR spectroscopic investigation, Applied $\mathrm{Ca}$ talysis A, 243, 81-92(2003).

16) V. Van den Bergh, H. Coeckelberghs, $H$. Vankerckhoven, F. Compernolle and C. Vinckier : Study of the carbonyl products of terpene/OH radical reactions: detection of the 2,4-DNPH derivatives by HPLC-MS, Analytical and Bioanalytical Chemistry, 379, 484-494(2004). 